\title{
FEATURES OF INTEGRATED MARKETING COMMUNICATIONS OF BANKS
}

\author{
Mariana Demko, PhD Student \\ Ivan Franko National University of Lviv
}

\begin{abstract}
(C) Demko M., 2020.
Стаття отримана редакиією 24.09.2020 p.

The article was received by editorial board on 24.09.2020
\end{abstract}

Introduction. The marketing communications are an important structural component of commercial banks. They serve as information support and an effective tool for interaction with the main subjects of banking and market activities, customers, partners. Today, marketing communications play an important role in making and implementing marketing decisions of banking. However, the task is the most effective combination of their various components: bank advertising (image, product), PR-activities (including, sponsorship), sales promotion, personal (personal) sales.

Analysis of recent researches and publications. Integrated marketing communications have been studied by many scientists. Scientists consider integrated marketing communications as: concept (Kotler F., Armstrong G. [1, p. 749], Romanenko O. O. [2, p. 112]); planning concept (Bilova S.V. [3]); the concept of joining forces (Demkura T. [4, p. 211]); management coordination concept (Kurban O. V. [5, p. 44]); J. Burnett, S. Moriarty [6, p. 28]); special macro positioning of the brand (Biloshapka V. S. [7, p. 10]); strategic analysis, selection, application and control (Romanenko O. O.[2, p. 112]).

Setting objectives. The main purpose of the study is to clarify the essence and determine the features of integrated marketing communications in banking, to reveal the mechanism of action of integrated marketing communications, each structural tool in its synergistic unity gives a significant positive effect for successful banking.

Basic material and results. Relationships with actual or potential customers of the bank are communications that create a positive image and reputation of the bank, banking products and services, which promotes sales and strengthens its competitiveness and increases overall efficiency.

In the modern literature you can find the definitions of ,integrated marketing communications”, „integral marketing communications”, „integration marketing communications” (IMC). However, the essence of these concepts is the same - combining communication efforts and directing them in the necessary direction of the business entity [4, p. 211].

Over the last two decades, integrated marketing communications have been actively developed and applied in world science and practice, and in particular in the marketing activities of banks. According to Remez Yu. B., ,on the one hand, they combine all types of market (marketing) communications: advertising, public relations, direct marketing, sales promotion, brand communications. In addition, the means of communication are integrated, which allows you to send targeted audiences consistent, convincing marketing appeals that help achieve the company's goals”. The author also notes that „the integration of marketing communications requires that in the future, advertisers will need to conduct media planning so directly, and respond to market changes in real time so quickly that there will be a tendency to combine all processes in one place" $[9$, p. 133].

A number of scientists note the need to consider the integrated marketing communications of banks through the prism of:

1) institutional factors that form the mental and pragmatic basis of the participants in the communicative process;

2) communicative and managerial qualities in relation to the formation of the environment, the organization of a favorable atmosphere of information exchange, which provide for the activation of analytical, prognostic and other intellectual processes [10, p. 77]. 
Integrated marketing communications are relevant and important in the use of banks in their activities to achieve marketing goals, in particular:

- in the promotion of banking products and the provision of banking services;

- creation of competitive advantages;

- increasing the attractiveness of the bank;

- formation and maintenance of a positive image of the bank.

The goal, task and properties of integrated marketing communications in the activities of banks are presented in Fig. 1.

\begin{tabular}{|c|c|c|}
\hline \multicolumn{3}{|c|}{ Integrated marketing communications in the activities of banks } \\
\hline Goal & Task & Properties \\
\hline $\begin{array}{l}\text { Effective informing } \\
\text { about the bank and } \\
\text { its products to } \\
\text { stimulate sales, } \\
\text { promote banking } \\
\text { products, build } \\
\text { customer loyalty, } \\
\text { create a positive } \\
\text { image of the bank }\end{array}$ & $\begin{array}{l}\text { - inform about the bank's } \\
\text { novelties } \\
\text { - be interested in buying } \\
\text { the product } \\
\text { - remind about the } \\
\text { product, service } \\
\text { - increase the } \\
\text { attractiveness of the bank } \\
\text { - to achieve maximum } \\
\text { economic efficiency }\end{array}$ & $\begin{array}{l}\text { - informing and agreeing, building } \\
\text { favorable relation } \\
\text { - integration of marketing } \\
\text { communications and their integration } \\
\text { with other components of the } \\
\text { marketing complex } \\
\text { - efficiency in interaction } \\
\text { - the occurrence of a synergistic } \\
\text { effect } \\
\text { - formation of a holistic look of the } \\
\text { brand }\end{array}$ \\
\hline
\end{tabular}

Fig. 1. The goal, task and properties of integrated marketing communications in the activities of banks

\section{Source: own development}

For a deeper understanding of the essence of integrated marketing communications, it is advisable to consider and group them (Fig. 2).

So, most authors believe that integrated marketing communications are:

- the concept of marketing communication management.

Some authors note that integrated marketing communications:

- special macro positioning of the brand;

- strategic analysis, selection, application and control over all means of marketing communications.

All definitions characterize integrated marketing communications as a universal means of achieving marketing goals of companies and banks in particular. In our opinion, integrated marketing communications of banks are a Totality of marketing communications that form a system of marketing communications and cover a wide range of actions with promotion tools, their interaction with the emergence of a synergistic effect, and each structural instrument of which in its synergetic unity gives a significant positive effect for successful banking, and thus creates a positive image of the bank. The mechanism of action of integrated marketing communications in the activity of banks is clearly presented in fig. 3 .

The mechanism of action of integrated marketing communications is an effective tool for communication activities of banks, because the interaction of marketing communication tools in their synergistic unity creates a positive effect for activities banking.

Integrated marketing communications are relevant in that they provide information about banking products and services, as well as help consumers show interest in a particular bank. Thus, it indicates an improvement in the visibility and popularity of banks. Banks have become noticeable among consumers due to the introduction of integrated marketing communications tools [11, p. 38]. 


\begin{tabular}{|c|c|}
\hline \multicolumn{2}{|c|}{ Conceptual approaches to the essence of integrated marketing communications } \\
\hline Approaches & The essence of integrated marketing communications \\
\hline Concept & $\begin{array}{l}\text { The concept according to which the company carefully considers and } \\
\text { coordinates the work of communication channels (Kotler F., } \\
\text { Armstrong G.) [1, p. } 749] \text {. Is a practical application of the concept of } \\
\text { generality of communications (Romanenko O. O.) [2, p. 112]. }\end{array}$ \\
\hline Planning concept & $\begin{array}{l}\text { The concept of planning marketing communications, based on the } \\
\text { need to assess the strategic role of each of its elements, in the } \\
\text { promotion strategy, finding their optimal combination (Bilova S. V.) } \\
\text { [3]. It is associated with the need to assess the strategic role of } \\
\text { individual areas and find the optimal combination (American } \\
\text { Association of Advertising Agencies) [8, p. 692]. }\end{array}$ \\
\hline $\begin{array}{l}\text { The concept of } \\
\text { joining forces }\end{array}$ & $\begin{array}{l}\text { The concept of joining forces of the business entity to form and } \\
\text { implement a multi-channel synchronized system of interaction with } \\
\text { target audiences (Demkura T.) [4, p. 211]. }\end{array}$ \\
\hline $\begin{array}{l}\text { Management } \\
\text { coordination concept }\end{array}$ & $\begin{array}{l}\text { Management coordination concept of all communication channels in } \\
\text { synergetic combination (Kurban O. V.) [5, p. 44]. }\end{array}$ \\
\hline Combine tools & $\begin{array}{l}\text { Combines all the tools of marketing communications (J. Burnett and } \\
\text { S. Moriarty) [6, p. 28] }\end{array}$ \\
\hline $\begin{array}{l}\text { Special macro } \\
\text { positioning of the } \\
\text { brand }\end{array}$ & $\begin{array}{l}\text { Special macro positioning of the brand, combination of different } \\
\text { types of advertising, integration of methods and tools } \\
\text { (Biloshapka V.S.) }\lceil 7, \text { p. } 10\rceil\end{array}$ \\
\hline $\begin{array}{l}\text { Strategic analysis, } \\
\text { selection, } \\
\text { application and } \\
\text { control }\end{array}$ & $\begin{array}{l}\text { Strategic analysis, selection, application and control over all means of } \\
\text { marketing communications (Romanenko O. O.) } \\
{[2, \text { p. } 112]}\end{array}$ \\
\hline
\end{tabular}

Fig. 2. Systematization of approaches to the essence of integrated marketing communications Source: compiled on the basis of [1-8]

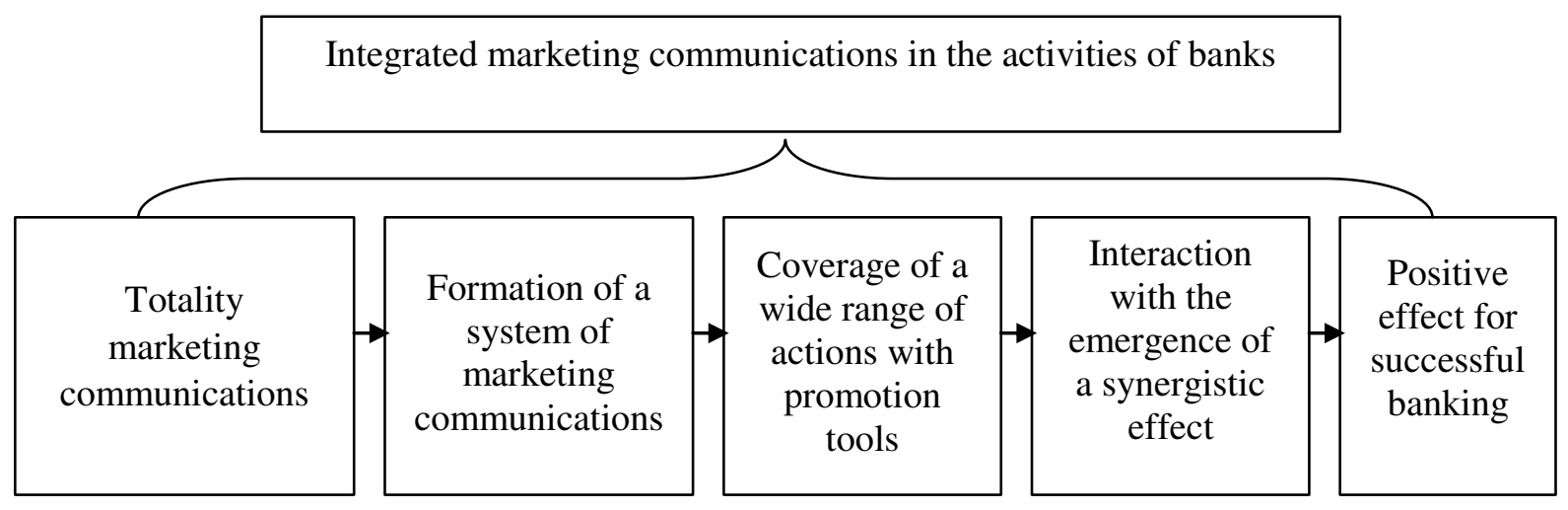

Fig. 3. The mechanism of action of integrated marketing communications in the activities

Source: own development of banks 
The very integration marketing communications in banks is to combine different marketing communications tool. The integration of the bank's marketing communications allows to form the bank integrated marketing communications as a holistic system of banking activity, which in turn will provide an opportunity to increase the number of consumers, interest and attract more customers, apply the latest products. For example, a combination of advertising and PR helps to stay competitive. Combining communication tools will have a greater effect than the impact of individual tools. When the promotion tools interact with the emergence of a synergistic effect, the goals of the bank are achieved.

\section{Conclusions and prospects for further research.}

From theoretical research:

- the purpose, tasks and features of the integrated marketing communications of banks for achievement of the marketing purposes and increase of successful activity of banks are formulated;

- conceptual approaches to the essence of integrated marketing communications as a universal tool for achieving marketing goals are identified;

- the author's definition of integrated marketing communications of banks on the basis of the formed conceptual approaches to the essence of integrated marketing communications and definitions of authors is offered, and also the mechanism of action of integrated marketing communications as an effective tool of communication activity is formed.

According to research results, integrated marketing communications of Ukrainian banks contribute to achieving the bank's attractiveness, the formation of a high level of customer service, the organization of information support of the bank. The introduction of integrated marketing communications in banking will provide an opportunity to improve the bank's activities and relationships with consumers, as well as attract new customers, improve the quality of customer service and banking services. The result of such actions should be an increase in the level of banking service.

\section{REFERENCES:}

1. Kotler F. Fundamentals of marketing / F. Kotler, G. Armstrong // 9th edition : trans. from English. - M.: Publishing house „Williams”, 2003. - 1200 p.

2. Romanenko O. O. The essence and process of formation of integrated marketing communications / O. O. Romanenko // Economic Bulletin of NMU, 2010. - No 1. - P. 112-119.

3. Bilova S.V. The concept of integrated marketing communications. URL: http://intkonf.org/bilova-sv-kontseptsiya-integrovanih-marketingovih-komunikatsiy/

4. Demkura T. Formation and development of integrated marketing communications : theoretical aspect / T. Demkura // Galician Economic Bulletin, 2013. - No 4 (43). - P. 207-214. - (Marketing technologies of enterprises in the modern scientific and technical environment).

5. Kurban O. V. Modern marketing communications and algorithmization of business processes // Integrated Communications, 2016. - P. 43-48.

6. Burnett J., Moriarty S. Marketing communications : an integrated approach / trans. from English. under ed. S. H. Bozhuk. - SPb : Peter, 2001. - 864 p. : Il. - (Series „Marketing for professionals”).

7. Biloshapka V. S. Creating a bank brand / V. S. Biloshapka // Bulletin of KNEU. - 2008. - No 5. - P. 7-13. $896 \mathrm{p}$.

8. Kotler F. Marketing Management / Per. from English - Saint Petersburg : Peter com, 1999.-

9. Remez Yu. B. Evolution of integrated marketing communications / Yu. B. Remez // Formation of market economy. - 2015. - Issue 19. - P. 132-139.

10. Humeniuk V. V. Technology of intellectualization in the development of integrated marketing communications of banks / V. V. Humeniuk, S. Ya. Kis, O. T. Levandivskyi // Modernization of the financial and credit system: thesis add. All-Ukrainian scientific-practical conf. (Kyiv, March 27, 2018) / resp. ed. N. P. Shulha. - Kyiv : Kyiv Nat. Trade and Economy University, 2018. - 160 p. - P. 76-78.

11. Oluwafemi Adesanoye. Integrated Marketing Communication Tools and Customers' Perception and Attitudes to the Brands of Selected Nigerian Banks / Oluwafemi Adesanoye // Acta Universitatis Danubius. Communicatio. AUDC, Vol.13, No.2/2019, pp. 26-40. URL:http:// journals.univ-danubius.ro/index.php/communicatio/article/view/6116. 
УДК 336.71:[658.8:007]

JEL: G21; M30; M39

Демко Мар'яна Ярославівна, аспірантка. Львівський національний університет імені Івана Франка. Особливості інтегрованих маркетингових комунікацій банків. Досліджено сутність і особливості інтегрованих маркетингових комунікацій та їх роль у досягненні успішного функціонування банків на ринку. В умовах економічної нестабільності банки здійснюють пошук найефективніших маркетингових інструментів для просування бренду. Тому значно збільшилася роль інтегрованих маркетингових комунікацій у діяльності банків. Інтегровані маркетингові комунікації зміцнюють конкурентну стійкість банку на ринку, формують імідж банку, підвищують просування банківських продуктів, надання банківських послуг та ефективність банківської діяльності. Сформульовано мету, завдання і властивості інтегрованих маркетингових комунікацій банків для досягнення маркетингових цілей та підвищення успішної діяльності банків. Сформовано концептуальні підходи до сутності інтегрованих маркетингових комунікацій як універсального інструменту досягнення маркетингових цілей (концепція; концепція планування; концепція об'єднання зусиль; управлінська концепція координації; об'єднання інструментів; особливе макропозиціонування бренду; стратегічний аналіз, вибір, застосування та контроль). Запропоновано авторське визначення інтегрованих маркетингових комунікацій банків на основі сформованих концептуальних підходів до сутності інтегрованих маркетингових комунікацій і визначень авторів. На основі цього визначення сформовано механізм дії інтегрованих маркетингових комунікацій як ефективного інструменту комунікаційної діяльності, оскільки при взаємодії інструментів маркетингових комунікацій у своїй синергетичній єдності вони створюють позитивний ефект для успішної банківської діяльності. Ефективне управління банківською діяльністю здійснюється при взаємодії інструментів просування 3 виникненням синергетичного ефекту, оскільки при цьому досягаються поставлені маркетингові цілі діяльності банку.

Ключові слова: інтегровані маркетингові комунікації, інтеграція, сукупність та система маркетингових комунікацій.

UDC 336.71:[658.8:007]

JEL: G21; M30; M39

Demko Mariana Yaroslavivna, PhD Student. Ivan Franko National University of Lviv. Features of Integrated Marketing Communications of Banks. The essence and features of integrated marketing communications and their role in achieving successful functioning of banks in the market are studied. In conditions of economic instability, banks are looking for the most effective marketing tools to promote the brand. Therefore, the role of integrated marketing communications in the activities of banks has significantly increased. Integrated marketing communications strengthen the bank's competitive stability in the market, form the image of the bank, increase the promotion of banking products, provide banking services and efficiency of banking. The purpose, tasks and properties of integrated marketing communications of banks to achieve marketing goals and increase the successful operation of banks are formulated. Conceptual approaches to the essence of integrated marketing communications as a universal tool for achieving marketing goals (concept; planning concept; the concept of joining forces; management coordination concept; combine tools; special macro positioning of the brand; strategic analysis, selection, application and control). The author's definition of integrated marketing communications of banks on the basis of the formed conceptual approaches to the essence of integrated marketing communications and definitions of authors is offered. On the basis of this definition the mechanism of action of integrated marketing communications as an effective tool of communication activity is formed as at interaction of tools of marketing communications in the synergetic unity create positive effect for successful banking activity. Effective management of banking activities is carried out by the interaction of promotion tools with the emergence of a synergistic effect, as this achieves the marketing goals of the bank.

Key words: integrated marketing communications, integration, totality and system of marketing communications. 